\title{
Pathway of propionate formation from ethanol in Pelobacter propionicus
}

\author{
B. Schink ${ }^{1}$, D. R. Kremer ${ }^{2}$, and T. A. Hansen ${ }^{2}$ \\ 1 Fachbereich Biologie - Mikrobiologie, Philipps-Universität, D-3550 Marburg, Federal Republic of Germany \\ ${ }^{2}$ Laboratorium voor Microbiologie, Rijksuniversiteit Groningen, Kerklaan 30, NL-9751 NN Haren, The Netherlands
}

\begin{abstract}
Whole cells of Pelobacter propionicus fermented $\left(1-{ }^{13} \mathrm{C}\right)$ ethanol and $\mathrm{CO}_{2}$ to nearly equal amounts of $\left(2-{ }^{13} \mathrm{C}\right)$ and $\left(3-{ }^{13} \mathrm{C}\right)$ propionate and to $\left(1-{ }^{13} \mathrm{C}\right)$ acetate indicating a randomizing pathway of propionate formation. Enzymes involved in the fermentation were assayed in cell-free extracts and cetyltrimethylammonium bromide-permeabilized cells grown with ethanol as sole substrate. Alcohol dehydrogenase, aldehyde dehydrogenase (benzylviologen-reducing), phosphate acetyl transferase, acetate kinase, pyruvate synthase, methylmalonyl CoA: pyruvate transcarboxylase, propionyl CoA: succinate CoA transferase, and the enzymes of the succinate-methylmalonyl CoA pathway all were detected at activities sufficient to be involved in ethanol fermentation. Very low amounts of a b-type cytochrome were detected in ethanol-grown cells $\left(46 \mathrm{nmol} \cdot \mathrm{g}\right.$ protein $\left.{ }^{-1}\right)$. Low cell yields obtained with ethanol as substrate indicate that $P$. propionicus does not conserve energy by electron transport-linked fumarate reduction. Despite the presence of a hydrogenase and a shift in the fermentation of lactate towards the formation of more propionate in the presence of hydrogen, $P$. propionicus was unable to catalyze the reduction of acetate and $\mathrm{CO}_{2}$ to propionate, unlike Desulfobulbus propionicus.
\end{abstract}

Key words: Propionate formation - Ethanol fermentation - Succinate pathway - Pelobacter propionicus Cytochrome b - Anaerobic electron transport - Pyruvate synthase

Propionate is formed as reduced end product of sugar and lactate fermentation by the Gram-positive Propionibacterium spp. and Arachnia propionica, as well as some Gramnegative strict anaerobes such as Selenomonas ruminantium, Anaerovibrio lipolytica, Veillonella alcalescens, Propionispira arboris, and Bacteroides fragilis. All these species use the socalled succinate pathway for propionate formation in which intermediately formed C-4 dicarboxylic acids serve as electron acceptors. Succinate is rearranged via its $\mathrm{CoA}$ derivative to methylmalonyl $\mathrm{CoA}$ which is decarboxylated and eventually yields propionate (see e.g. Swick and Wood 1960; Allen et al. 1964; Galivan and Allen 1968; de Vries et al. $1977 \mathrm{~b}$; Thompson et al. 1984). A few other strict anaerobes such as Megasphaera elsdenii, Bacteroides ruminicola, and Clostridium propionicum (Brockmann and Wood 1975;

Offprint requests to: $\mathrm{B}$. Schink
Leaver et al. 1955; Wallnöfer and Baldwin 1967) form propionate via the acrylate pathway which, contrary to the succinate pathway, does not involve a symmetrical intermediate and, therefore, does not randomize the distribution of selectively labeled carbon atoms. Experiments with propionate labeled in the $\mathrm{C}$-atoms 2 or 3 indicated that also methanogenic degradation of propionate in enrichment cultures, sediments, and sewage sludge employs the succinate pathway (Koch et al. 1983; Schink 1984). Enrichments with ethanol or 2,3-butanediol lately led to the isolation of bacteria which form propionate from C-2 compounds (Samain et al. 1982; Laanbroek et al. 1982; Schink 1984). These findings proved that propionate is not only produced during breakdown of more complex substrates, e.g. sugars, but also by fermentation of C-2 compounds with concomitant reduction of carbon dioxide. One of these bacteria, Desulfobulbus propionicus, is a sulfate-reducing bacterium which under hydrogen/carbon dioxide atmosphere forms increased of propionate and less acetate (Laanbroek et al. 1982; Stams et al. 1984). Also some other Gram-negative propionate formers such as Propionispira arboris (Schink et al. 1982; Thompson et al. 1984) contain hydrogenases which may attribute an important role as hydrogen sink to these bacteria and to propionate formation in a complex anoxic bacterial community. In the present study, the pathway of propionate formation from ethanol in Pelobacter propionicus is elucidated. Special emphasis was laid on the question how the $\mathrm{C}_{3}$ skeleton is formed from $\mathrm{C}_{2}$ precursors and to what extent hydrogen affects propionate fermentation by this bacterium.

\section{Materials and methods}

Cultivation. Pelobacter propionicus strain Ott Bd 1 (Schink 1984) was grown in a carbonate-buffered sulfide-reduced mineral salts medium as described earlier (Schink and Pfennig 1982; Schink 1984). A similar medium was used for growth of Desulfobulbus propionicus strain 1 pr 3 . Growth experiments were carried out at $28-30^{\circ} \mathrm{C}$ in $20 \mathrm{ml}$ glass tubes sealed with rubber-lined screw caps or butyl rubber septa (Bellco, Vineland, USA). Growth was followed by direct turbidity measurement with a Bausch and Lomb Spectronic 70 spectrophotometer at $650 \mathrm{~nm}$ wavelength. Larger amounts of cells were grown in screw cap bottles or 101 bottles sealed with rubber stoppers under $\mathrm{N}_{2} / \mathrm{CO}_{2}(80 /$ $20 \%$ ) atmosphere.

Preparation of cell-free extracts. Cells were harvested at the late logarithmic growth phase by centrifugation, washed 
once with either $100 \mathrm{mM}$ Tris-HCl buffer, $\mathrm{pH} 7.8$, or $50 \mathrm{mM}$ potassium phosphate buffer, $\mathrm{pH} 7.0$, and stored as wet cell paste anaerobically at $-20^{\circ} \mathrm{C} .1 \mathrm{~g}$ of wet cell paste was suspended in $2 \mathrm{ml}$ of the respective buffer containing $1 \mathrm{mM}$ dithiothreitol and $2 \mathrm{mM} \mathrm{MgCl}$. Cell-free extracts were prepared anaerobically under $\mathrm{N}_{2}$ either by French press treatment at 1450 bar or by ultrasonic disintegration. After removal of cell debris by centrifugation at $10,000 \times g$ for $15 \mathrm{~min}$, the supernatant was stored oxygen-free in a butyl rubber-sealed screw cap tube at $0^{\circ} \mathrm{C}$. Some enzyme assays were also carried out with cell suspensions permeabilized with cetyltrimethylammonium bromide (modified after Friedrich et al. 1981). Intact cells $(1-50 \mu$ of a suspension with $5-10 \mathrm{mg}$ protein $\cdot \mathrm{ml}^{-1}$ ) were transferred by syringes into the anaerobically sealed cuvettes after removal of free oxygen (see below), and $5-20 \mu \mathrm{l}$ of a $0.5 \%(\mathrm{w} / \mathrm{v})$ aqueous cetyltrimethylammonium bromide solution was added 2$5 \mathrm{~min}$ before the reaction was started.

Enzyme assays. Enzyme assays were carried out anaerobically at $30^{\circ} \mathrm{C}$ in $1 \mathrm{ml}$ cuvettes with $1 \mathrm{~cm}$ light path. The cuvettes carried Thunberg-type glass tops which allowed addition of the starting reagent by tipping, and were sealed with rubber septa. The reagent mixture was gassed with oxygen-free nitrogen gas for at least $5 \mathrm{~min}$ before the cell extract was added. A Perkin Elmer 124 or a Zeiss PM 4 spectrophotometer was used.

Pyruvate synthase (pyruvate benzylviologen oxidoreductase) was assayed with benzyl viologen as electron acceptor in the presence and absence of coenzyme $A$ according to Odom and Peck (1981). Aldehyde dehydrogenase was measured in a similar manner with benzyl viologen as electron acceptor in the presence and absence of coenzyme A. The reaction was started by injecting acetaldehyde from a $100 \mathrm{mM}$ stock solution to $1 \mathrm{mM}$ final concentration into the prereduced reaction mixture. Hydrogenase was assayed with benzyl viologen as described earlier (Schink 1985a). Alcohol dehydrogenase, NAD-dependent lactate dehydrogenase, acetate kinase, and phosphate acetyltransferase were measured by standard procedures (Bergmeyer 1974). NAD-independent lactate dehydrogenase was assayed after Stams and Hansen (1982). Malate dehydrogenase, fumarase, succinate dehydrogenase, and methylmalonyl CoA: pyruvate transcarboxylase were measured according to Stams et al. (1984) Methylmalonly CoA decarboxylase was assayed after Hilpert and Dimroth (1983), propionyl CoA: succinate CoA transferase after Hilpert et al. (1984). Fumarate reductase was measured after Boonstra et al. (1975), pyruvate carboxylase after Scrutton et al. (1969), phosphoenolpyruvate carboxylase after Maeba and Sanwal (1969), phosphoenolpyruvate carboxykinase after Lane et al. (1969), phosphoenolpyruvate carboxytransphosphorylase after Wood et al. (1969), malic enzyme after Hatchikian and LeGall (1970) and succinyl CoA synthetase after both Dijkhuizen et al. (1980) and Bridger et al. (1969). The overall reaction from succinate to propionate was followed in a coupled spectrophotometric assay. The mixture contained $500 \mu 150 \mathrm{mM}$ potassium phosphate buffer, $\mathrm{pH} 7.5 ; 100 \mu \mathrm{l}$ $2 \mathrm{mM} \mathrm{NADH} ; 100 \mu \mathrm{l} 50 \mathrm{mM}$ sodium pyruvate; $100 \mu \mathrm{l}$ $1 \mathrm{mM}$ cobalt chloride; $50 \mu \mathrm{l} 1 \mathrm{mM}$ coenzyme $\mathrm{B}_{12}$ (adenosylcobalamin), and $50 \mu \mathrm{l}$ permeabilized cells. The reaction was started by addition of $100 \mu \mathrm{l} 20 \mathrm{mM}$ succinate in the presence and absence of catalytic amounts of ATP, coenzyme A, or succinyl CoA.

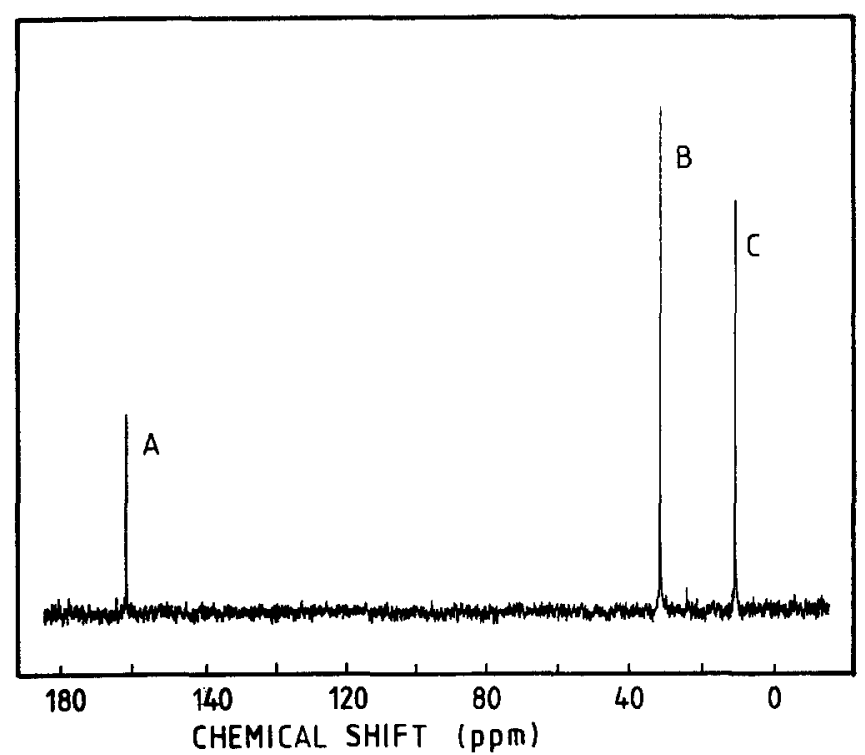

Fig. 1. NMR-spectrum of products formed during growth of Pelobacter propionicus with $\left[1-{ }^{13} \mathrm{C}\right]$ ethanol. $A: \mathrm{CH}_{3}^{13} \mathrm{COOH} ; B$ : $\mathrm{CH}_{3}^{13} \mathrm{CH}_{2} \mathrm{COOH} ; \mathrm{C}:{ }^{13} \mathrm{CH}_{3} \mathrm{CH}_{2} \mathrm{COOH}$

Cytochromes. Cytochromes were determined in cell-free extracts and membrane preparations obtained by ultracentrifugation $(1 \mathrm{~h}$ at $120,000 \times g)$. Redox difference spectra were measured in a Shimadzu UV 300 double-beam spectrophotometer; extracts were reduced with dithionite or oxidized by air and ferricyanide. Cytochromes were identified by their typical absorption bands (Dickerson and Timkovich 1975) and cytochrome $b$ was quantified assuming an absorption coefficient of $17.5 \mathrm{~cm}^{2} \cdot \mu \mathrm{mol}^{-1}$ for the $\alpha$-band (Deeb and Hager 1964).

Fermentation of $1-{ }^{13} \mathrm{C}$ ethanol. $P$. propionicus was pregrown under $\mathrm{N}_{2} / \mathrm{CO}_{2}(80: 20)$ in two $17 \mathrm{ml}$ screw-cap tubes sealed with butyl rubber septa containing $10 \mathrm{ml}$ medium with $10 \mathrm{mM}$ unlabeled ethanol. $\left(1-{ }^{13} \mathrm{C}\right)$ ethanol was added to a final concentration of $10 \mathrm{mM}$. After 1 week of incubation samples were taken, and the supernatant after centrifugation was analyzed. ${ }^{13} \mathrm{C}$ NMR spectra were taken as described earlier (Stams et al. 1984).

Chemical analyses. Alcohols and fatty acids were assayed by gas chromatography as described earlier (Schink and Pfennig 1982). Protein was determined after Kuenen and Veldkamp (1972).

Chemicals. All chemicals used were of anaytical grade and obtained from Merck, Darmstadt, FRG, or Fluka, NeuUlm, FRG. Biochemicals and enzymes were purchased from Boehringer, Mannheim, FRG, and Sigma Chemical Co., München, FRG. $\left[1-{ }^{13} \mathrm{C}\right]$ ethanol was obtained from Merck, Sharp and Dohme Ltd., Canada, through IC Chemicalien, München, FRG.

\section{Results}

\section{Fermentation of $\left[1-{ }^{13} \mathrm{C}\right]$ ethanol}

Ethanol is fermented by Pelobacter propionicus to acetate and propionate in a 1:2 ratio (Schink 1984). With $\left[1{ }^{13} \mathrm{C}\right]$ ethanol, the fermentation led to nearly equal amounts $(100: 92)$ of $\left[3-{ }^{13} \mathrm{C}\right]$ propionate and $\left[2-{ }^{13} \mathrm{C}\right]$ propionate, together with $\left[1-{ }^{13} \mathrm{C}\right]$ acetate (Fig. 1). This result indicates that 


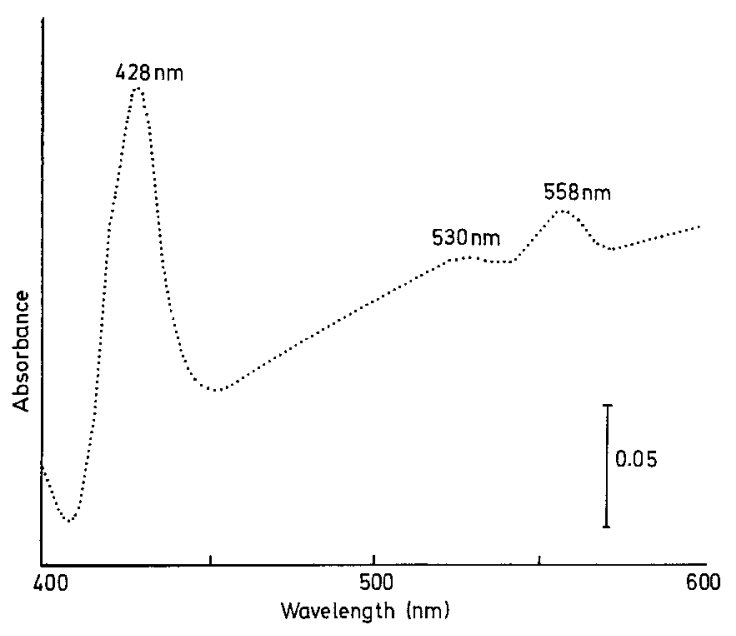

Fig. 2. Redox difference spectrum of cell-free extracts of Pelobacter propionicus grown with ethanol. The cell extract contained $9.9 \mathrm{mg}$ protein $\cdot \mathrm{ml}^{-1}$

$P$. propionicus uses a randomizing pathway for propionate formation.

\section{Enzyme studies}

Measurements of enzyme levels in cell-free extracts of ethanol-grown cells corroborated this finding (Table 1): Most enzymes of the $\mathrm{C}_{4}$ dicarboxylic acid reduction pathway (malate dehydrogenase, fumarase, fumarate reductase) were detected at high or moderate activities. Aldehyde dehydrogenase and pyruvate synthase (benzylviologen-reducing) both were present at high activities, and were both dependent on coenzyme A. No acetaldehyde-dependent NAD(P) reduction was detected. NAD-dependent alcohol dehydrogenase, phosphate acetyl transferase and acetate kinase were highly active. Propionate kinase activity was about $60 \%$ lower than acetate kinase. Proof of a pyruvate-carboxylating enzyme caused serious problems as long as extracts of frozen cells were used for enzyme assays. Finally, a methylmalonylCoA: pyruvate transcarboxylase was found in potassium phosphate-buffered fresh cell suspensions permeabilized with cetyltrimethylammonium bromide. It turned out that this enzyme was completely inactivated by freezing and that it was inhibited considerably by the Tris buffer originally used in the enzyme assay; $2 \mathrm{mM}$ Tris inhibited the reaction by about $50 \%$. Propionyl CoA: succinate CoA transferase was also detected as well as hydrogenase and small activities of an NAD-independent L-lactate dehydrogenase. The reaction sequence from succinate to propionate was assayed as a whole by a coupled optical test in which pyruvate-dependent oxaloacetate formation was measured. The reaction was only possible in the presence of catalytic amounts of either succinyl CoA or adenosine triphosphate and coenzyme A.

\section{Cytochromes}

In the original description of $P$. propionicus (Schink 1984) it was reported that this organism has no cytochromes. These difference spectra were recorded with extracts of butanediolgrown cells by a comparably insensitive Gilford spectrophotometer. Reexamination of cell extracts and membrane preparations with a new, highly sensitive Shimadzu UV 300 spectrophotometer revealed the presence of small amounts
Table 1. Specific activities $\left(\mu \mathrm{mol} \cdot \mathrm{min}^{-1} \cdot \mathrm{mg}\right.$ protein $\left.{ }^{-1}\right)$ of enzymes detected in Pelobacter propionicus

\begin{tabular}{|c|c|c|}
\hline Enzyme & $\begin{array}{l}\mathrm{EC} \\
\text { number }^{\mathrm{e}}\end{array}$ & Activity \\
\hline \multicolumn{3}{|l|}{ Alcohol dehydrogenase, } \\
\hline NAD-dependent & 1.1.1.1 & 1.73 \\
\hline Aldehyde dehydrogenase $\mathrm{e}^{\mathrm{a}, \mathrm{b}}$ & $?$ & 2.62 \\
\hline Phosphate acetyl transferase & 2.3.1.8 & 5.18 \\
\hline Acetate kinase & 2.7.2.1 & 2.24 \\
\hline Pyruvate synthase $^{a, b}$ & 1.2 .7 .1 & 3.23 \\
\hline \multicolumn{3}{|l|}{ Methylmalonyl CoA: } \\
\hline pyruvate transcarboxylase & 2.1.3.1 & 0.553 \\
\hline Malate dehydrogenase, NAD-dependent & 1.1.1.37 & 6.12 \\
\hline Fumarase & 4.2.1.2 & 2.01 \\
\hline Fumarate reductase & 1.3.1.6(?) & 0.068 \\
\hline Succinate dehydrogenase ${ }^{c}$ & 1.3 .99 .1 & 0.139 \\
\hline \multicolumn{3}{|l|}{ Propionyl CoA: } \\
\hline succinate CoA transferase & 2.8.3.1(?) & 1.10 \\
\hline Hydrogenase $^{\mathrm{a}}$ & 1.18 .99 & 0.218 \\
\hline L-Lactate dehydrogenase ${ }^{d}$ & 1.1.2.3 & 0.011 \\
\hline \multicolumn{3}{|l|}{ Overall reaction } \\
\hline succinate $\rightarrow$ propionate & - & 0.041 \\
\hline
\end{tabular}

Measured with benzyl viologen as electron acceptor

b Coenzyme A-dependent

c Measured with potassium ferricyanide as electron acceptor

d Measured with dichlorophenol indophenol as electron acceptor

e After International Union of Biochemistry (1984)

All enzymes were assayed in extracts of cells grown with $20 \mathrm{mM}$ ethanol. Methylmalonyl CoA:pyruvate transcarboxylase was assayed in fresh cell suspensions permeabilized with cetyltrimethylammonium bromide

Enzymes not detected: Lactate dehydrogenase (NAD-dependent), pyruvate carboxylase, phosphoenolpyruvate carboxylase, phosphoenolpyruvate carboxytransphosphorylase, phosphoenolpyruvate carboxykinase, malic enzyme, methylmalonyl coenzyme A decarboxylase, succinyl CoA synthetase

of cytochromes which were firmly bound to the membrane fraction (Fig. 2). From the absorption bands at 558, 530 and $428 \mathrm{~nm}$, a b-type cytochrome was identified. The absorption of the $\alpha$-band corresponds to a total concentration of $46 \mathrm{nmol}$ or $2.9 \mathrm{mg}$ cytochrome b per gram cell protein. Addition of hemin to the growth medium did not increase the cytochrome content of ethanol- or butanediol-grown cells.

\section{Metabolism of hydrogen}

Coculture experiments with $P$. propionicus and the hydrogen-oxidizing methanogen Methanospirillum hungatei gave no indication of a significant interspecies hydrogen transfer to the methanogen (Schink 1984). The question arose whether the hydrogenase enzyme present could function in hydrogen uptake. Growth experiments were carried out with various substrates under hydrogen $/ \mathrm{C}_{2}$ or nitrogen $/ \mathrm{CO}_{2}$ atmosphere, and growth and product formation were followed (Table 2). For comparison, Desulfobulbus propionicus was examined as well. The results show that neither the fermentation balance nor the growth yield of Pelobacter was significantly influenced by the presence of hydrogen with either acetate or ethanol as substrate. Only with lactate as substrate, hydrogen caused a slight inhibition of growth, and the ratio of propionate over acetate formed changed from 1.89 to 3.64. Desulfobulbus fermented ethanol or lactate to 
Table 2. Influence of hydrogen on growth and substrate conversion by Pelobacter propionicus and Desulfobulbus propionicus

\begin{tabular}{|c|c|c|c|c|c|}
\hline \multirow[t]{2}{*}{ Substrate } & \multirow{2}{*}{$\begin{array}{l}\text { Gas phase } \\
80 \% / 20 \%\end{array}$} & \multirow{2}{*}{$\begin{array}{l}\text { Maximum turbidity } \\
\text { reached } \mathrm{OD}_{650}\end{array}$} & \multicolumn{2}{|c|}{ Products formed $(\mathrm{mM})$} & \multirow{2}{*}{$\frac{\text { Ratio propionate }}{\text { acetate formed }^{\mathrm{b}}}$} \\
\hline & & & Acetate & Propionate & \\
\hline \multicolumn{6}{|c|}{ A. Pelobacter propionicus } \\
\hline No & $\mathrm{N}_{2} / \mathrm{CO}_{2}$ & 0.05 & 0.57 & 1.13 & - \\
\hline Acetate $5 \mathrm{mM}$ & $\mathrm{N}_{2} / \mathrm{CO}_{2}$ & 0.05 & 4.68 & 1.14 & - \\
\hline Acetate $5 \mathrm{mM}$ & $\mathrm{H}_{2} / \mathrm{CO}_{2}$ & 0.05 & 4.81 & 1.14 & - \\
\hline Ethanol $20 \mathrm{mM}$ & $\mathrm{N}_{2} / \mathrm{CO}_{2}$ & 0.19 & 6.01 & 11.0 & 1.82 \\
\hline Ethanol $20 \mathrm{mM}$ & $\mathrm{H}_{2} / \mathrm{CO}_{2}$ & 0.18 & 5.60 & 11.5 & 2.06 \\
\hline Lactate $20 \mathrm{mM}$ & $\mathrm{N}_{2} / \mathrm{CO}_{2}$ & 0.42 & 5.35 & 10.0 & 1.89 \\
\hline Lactate $20 \mathrm{mM}$ & $\mathrm{H}_{2} / \mathrm{CO}_{2}$ & 0.35 & 3.7 & 12.5 & 3.64 \\
\hline \multicolumn{6}{|c|}{ B. Desulfobulbus propionicus } \\
\hline No & $\mathrm{N}_{2} / \mathrm{CO}_{2}$ & 0.06 & 0.90 & 0.90 & - \\
\hline Acetate $5 \mathrm{mM}$ & $\mathrm{N}_{2} / \mathrm{CO}_{2}$ & 0.06 & 5.12 & 0.94 & - \\
\hline Acetate $5 \mathrm{mM}$ & $\mathrm{H}_{2} / \mathrm{CO}_{2}$ & 0.06 & 1.45 & 4.50 & - \\
\hline Ethanol $20 \mathrm{mM}$ & $\mathrm{N}_{2} / \mathrm{CO}_{2}$ & 0.13 & 7.0 & 12.3 & 1.86 \\
\hline Ethanol $20 \mathrm{mM}^{\mathrm{c}}$ & $\mathrm{H}_{2} / \mathrm{CO}_{2}$ & 0.09 & 5.7 & 8.0 & - \\
\hline Lactate $20 \mathrm{mM}$ & $\mathrm{N}_{2} / \mathrm{CO}_{2}$ & 0.33 & 5.5 & 9.6 & 1.89 \\
\hline Lactate $20 \mathrm{mM}^{\mathrm{d}}$ & $\mathrm{H}_{2} / \mathrm{CO}_{2}$ & 0.11 & 0.62 & 6.8 & - \\
\hline
\end{tabular}

a Overall products found in the culture medium after 10 days including the remnant products transferred with the inoculum

b Calculated for the net products formed

c $7.1 \mathrm{mM}$ ethanol was still left at the end of the experiment

d $13.6 \mathrm{mM}$ lactate was still left at the end of the experiment

Experiments were carried out in $20 \mathrm{ml}$ tubes containing $10 \mathrm{ml}$ medium under the atmosphere indicated. Tubes were sealed with butyl rubber septa and incubated lying on a slow shaker. Turbidity was followed over 10 days, and fermentation products were assayed at the end. All numbers given are means of at least 4 independent experiments in every case

acetate and propionate in the same ratio as Pelobacter did, however, with lower yields in both cases. Fermentation of ethanol and lactate was strongly inhibited by hydrogen, and the substrate had not been completely utilized after 10 days of incubation. Resting cells of Desulfobulbus converted acetate to propionate with hydrogen as electron donor, a reaction not observed with Pelobacter cells. This conversion was not associated with growth. Growth and fermentation balances of both bacteria were not influenced by addition of fumarate, neither in the presence nor in the absence of hydrogen or formate.

\section{Discussion}

\section{Pathway of propionate formation}

The pathway of propionate formation from ethanol by Pelobacter propionicus has been elucidated in the present study by ${ }^{13} \mathrm{C}$-NMR experiments and enzyme assays. The results can be combined into the metabolic scheme presented in Fig. 3. Oxidation of ethanol to acetate proceeds via acetaldehyde, acetyl-CoA, and acetyl phosphate. ATP is formed in the acetate kinase reaction. The electrons released in this oxidative branch of the metabolism are used for the reductive synthesis of propionate. High activities of a benzyl viologen - dependent pyruvate - oxidizing enzyme in ethanol-grown cells indicate the presence of a pyruvate: ferredoxin oxidoreductase (pyruvate synthase), an enzyme able to catalyze the reductive synthesis of pyruvate from acetyl CoA and carbon dioxide. We assume that the electron acceptor of the aldehyde dehydrogenase enzyme, probably a ferredoxin, functions as the electron donor in the pyruvate synthase reaction. This is the first report that pyruvate synthase operates towards pyruvate formation in the dissimilatory metabolism. In clostridia, it functions mainly in pyruvate degradation (Gottschalk 1986), and in many anaerobes growing with acetate as carbon source, it is the main step in formation of a $\mathrm{C}_{3}$ unit in the assimilatory metabolism. Operation of this enzyme in pyruvate formation in the dissimilatory metabolism creates an energetical problem: The equilibrium of this reaction is far on the side of acetyl CoA and reduced ferredoxin. Even if this enzyme cooperates closely with the exergonic aldehyde ferredoxin oxidoreductase reaction, the overall reaction:

acetaldehyde $+\mathrm{CO}_{2} \rightarrow$ pyruvate ${ }^{-}+\mathrm{H}^{+}$

is still an endergonic reaction $\left(\Delta \mathrm{G}_{0}^{\prime}=+11.3 \mathrm{~kJ}\right.$; Thauer et al. 1977) which would need to be pulled by a subsequent exergonic reaction. Unfortunately, the following pyruvate carboxylation reaction is again endergonic:

pyruvate $^{-}+\mathrm{CO}_{2} \rightarrow$ oxaloacetate ${ }^{2-}+\mathrm{H}^{+}$;

$\Delta \mathrm{G}_{\mathrm{o}}^{\prime}=+23.6 \mathrm{~kJ}$. The organism combines this carboxylation with methylmalonyl CoA decarboxylation in an almost energy-neutral reaction catalyzed by a transcarboxylase. Similar transcarboxylases have been found in the classical propionibacteria (Swick and Wood 1960; Wood 1972), in Arachnia propionica (Allen and Linehan 1977) and in Desulfobulbus propionicus (Stams et al. 1984). Pelobacter propionicus also links succinate activation to succinyl $\mathrm{CoA}$ with propionate formation from propionyl $\mathrm{CoA}$ in a CoA transferase reaction. Thus, the whole sequence of reactions from pyruvate to propionate is linked in two reaction cycles, and the efficiency of pyruvate removal depends on the efficiency of the operation of the entire reaction sequence following. This concept is of major importance for the energetics of this process (see below).

Due to the observed sensitivity of the transcarboxylase enzyme to freezing and to Tris buffer, we had for long times 


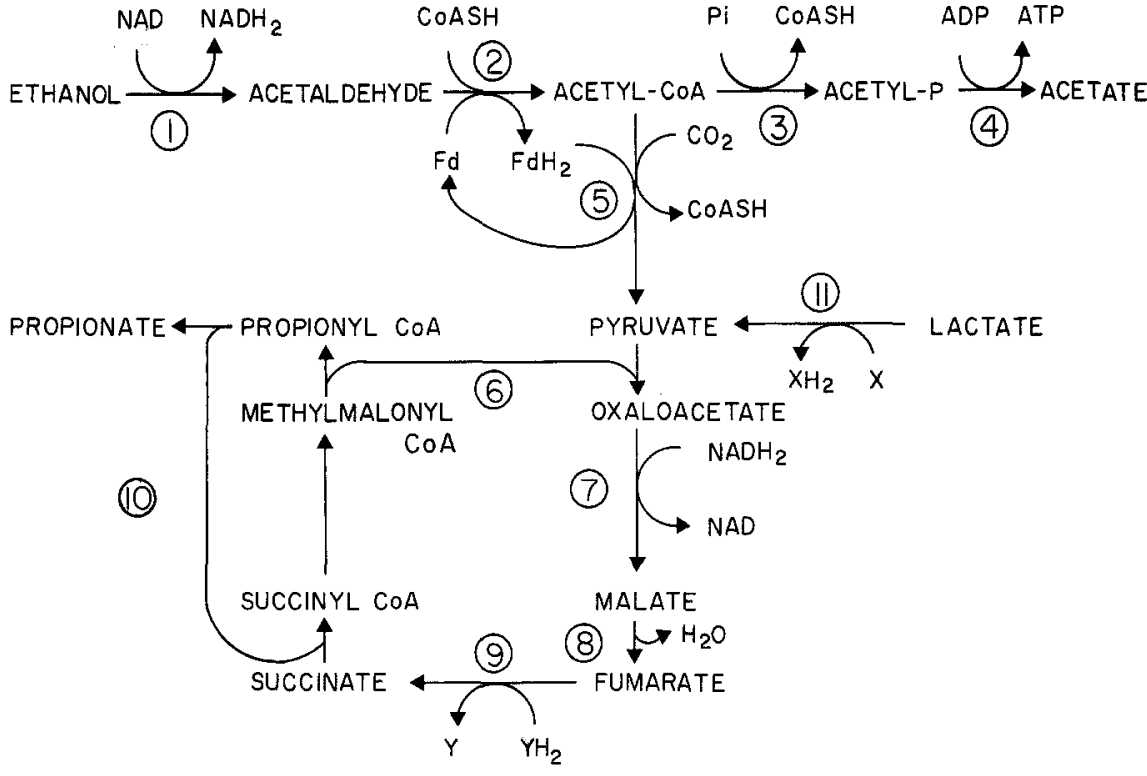

Fig. 3. Pathway of ethanol conversion to propionate by Pelobacter propionicus. Fd: Unknown low-potential electron carrier, probably ferredoxin; $x, y$ : hypothetical electron carriers for which dichlorophenol indophenol and reduced benzyl viologen substituted in the present study. Numbers in circles refer to the following enzymes: 1 : alcohol dehydrogenase; 2: aldehyde dehydrogenase; 3 : phosphate acetyltransferase; 4 : acetate kinase; 5 : pyruvate synthase; 6 : methylmalonyl $\mathrm{CoA}$ : pyruvate transcarboxylase; 7 : malate dehydrogenase; 8 : fumarase; 9 : fumarate reductase; 10: propionyl CoA:succinate CoA transferase; 11: lactate dehydrogenase problems in finding this enzyme and therefore checked for any other $\mathrm{C}_{3}$ carboxylating enzyme, however, without success. The possibility of involvement of a sodium gradient in the decarboxylation and carboxylation reactions as found with Veillonella alcalescens (Hilpert and Dimroth 1983) was also examined in growth experiments with varying additions of sodium chloride and the sodium ionophore monensin, but no indication of sodium participation in the metabolism of $P$. propionicus could be obtained (results not shown). The lack of methylmalonyl CoA decarboxylase in $P$. propionicus explains why this organism cannot grow with $\mathrm{C}_{4}$-dicarboxylic acids which are the preferred substrated of e.g. Veillonella alcalescens (Rogosa 1974).

Presence of a methylmalonyl CoA: succinate CoA transferase in Pelobacter propionicus is a major difference in comparison with Desulfobulbus propionicus in which both succinyl CoA synthesis and propionate release are ATP or ADP-dependent reactions (Stams et al. 1984). Nonetheless, Pelobacter also has phosphate propionyl transferase and propionate kinase when growing with propanol and acetate (Schink 1984); these enzyme activities were detected in cellfree extracts of ethanol-grown cells, too, and are probably by-functions of phosphate acetyl transferase and acetate kinase.

\section{Energetical aspects}

Fermentation of ethanol to propionate and acetate is less exergonic than the well-known conversion of lactate to propionate and acetate (calculations after Thauer et al. 1977):

3 lactate $\rightarrow 2$ propionate ${ }^{-}+$acetate $+\mathrm{HCO}_{3}^{-}+\mathrm{H}^{+}$ $\Delta \mathrm{G}_{\mathrm{o}}^{\prime}=-55.0 \mathrm{~kJ}$ per mol lactate,

3 ethanol $+2 \mathrm{HCO}_{3}^{-} \rightarrow 2$ propionate $^{-}+$acetate $^{-}+\mathrm{H}^{+}$ $+3 \mathrm{H}_{2} \mathrm{O}$

$\Delta \mathrm{G}_{0}^{\prime}=-41.5 \mathrm{~kJ}$ per mol ethanol.

The free energy changes of the two reactions differ by the free energy of lactate decarboxylation to ethanol $(-13.5 \mathrm{~kJ}$ per mol). The difference becomes even more pronounced if one takes into account that bicarbonate concentrations are usually in the millimolar range, and has major implications on the fermentation energetics.

The classical propionibacteria as well as Veillonella alcalescens ferment lactate to acetate and propionate with concomitant formation of 8.1 to $10.2 \mathrm{~g}$ dry cell matter per mol lactate (de Vries et al. 1973, $1977 \mathrm{a}, \mathrm{b}$ ); this corresponds to the formation of about $1 \mathrm{~mol}$ ATP per mol lactate (Stouthamer 1979). It is assumed that per 3 lactate fermented, 1 ATP is formed via acetate kinase and two via cytochrome b-dependent electron transport phosphorylation coupled to fumarate reduction (Stouthamer 1980). Both Desulfobulbus propionicus and Pelobacter propionicus exhibit by far lower yields when grown with lactate ( 2.9 and $2.7 \mathrm{~g}$ dry matter per mol; Stams et al. 1984; Schink 1984). Pelobacter forms even less cell material with ethanol as substrate $(1.75 \mathrm{~g}$ per mol) and yields of Desulfobulbus with ethanol are again lower $(0.87 \mathrm{~g}$ per mol). Although the higher yields of the classical lactate-fermenting propionibacteria may to some extent be explained by the comparably rich media used in yields assays, it is evident that the two ethanol-fermenting propionate formers Pelobacter and Desulfobulbus differ from the propionibacteria with respect to the amount of biochemically useful energy that they derive from the fermentation. The very low cytochrome $b$ content of ethanol-and butanediol-grown Pelobacter cells suggests that this organism does not conserve energy in the fumarate reductase reaction. Although at first sight this appears to be a loss for the overall fermentation energetics it might well be essential for this organism to pull the pyruvate synthase reaction and thus to allow rapid ethanol utilization. Dispensing with this phosphorylation reaction might help to speed up the whole propionate formation cycle and thus allow rapid ATP synthesis by the acetate kinase reaction. Desulfobulbus has by far higher cytochrome contents and is less efficient in ethanol conversion to propionate.

Desulfobulbus and Pelobacter differ by their ability to utilize externally provided hydrogen: Pelobacter is only slightly influenced by the presence of hydrogen during fermentation of ethanol or lactate and cannot synthetize propionate from acetate, hydrogen and $\mathrm{CO}_{2}$. Desulfobulbus is strongly inhibited hy hydrogen during ethanol or lactate utilization but resting cells convert acetate, hydrogen and 
$\mathrm{CO}_{2}$ to propionate. So far, we do not have an explanation yet for the inhibitory influence of hydrogen on Desulfobulbus fermentations. Propionate formation from acetate is an exergonic reaction which should allow ATP synthesis:

acetate $^{-}+\mathrm{HCO}_{3}^{-}+\mathrm{H}^{+}+3 \mathrm{H}_{2} \rightarrow$ propionate $^{-}+3 \mathrm{H}_{2} \mathrm{O} \Delta \mathrm{G}_{\mathrm{o}}^{\prime}=-76.8 \mathrm{~kJ}$ per mol.

However, activation of acetate requires at least 1 ATP, and this must be regenerated e.g. by electron transport phosphorylation during fumarate reduction. Desulfobulbus catalyzed this reductive conversion of acetate and bicarbonate to propionate which strongly suggests that in the formation of propionate the reduction of fumarate to succinate with hydrogen leads to ATP formation via the fumarate reductase system; this way the process would not consume ATP. An inability of Pelobacter to form ATP via the fumarate reductase system in the reduction of fumarate with hydrogen would explain its inability to catalyze the formation of propionate from acetate.

\section{Ecological aspects}

Formation of propionate from $\mathrm{C}_{2}$ compounds is of major importance considering the transformation of fermentation intermediates in anoxic ecosystems. A radiotracer study recently showed that a considerable fraction of intermediately formed ethanol can be transformed to methane and $\mathrm{CO}_{2}$ through propionate as intermediate, especially in slightly acidic environments (Schink et al. 1985). An earlier study reported formation of propionate together with acetate and butyrate from $\mathrm{CO}_{2}$ and hydrogen (Goldberg and Cooney 1981), a reaction series that can now be unterstood as a cooperation between homoacetogenic and "homopropionigenic" bacteria of the type of Desulfobulbus or Pelobacter propionicus. In most - probable - number enumeration experiments with methanol as substrate and freshwater sediments or sewage sludge as inoculum, we often observed traces of propionate formed together with acetate and methane (Schink, unpublished results). At the moment, it cannot be judged with certainty yet to which extent propionate formation can act as hydrogen sink in anoxic environments. Although propionate formation from acetate and $\mathrm{CO}_{2}$ provides nearly the same amount of energy $\left(-25.6 \mathrm{~kJ}\right.$ per $\left.\mathrm{mol} \mathrm{H}_{2}\right)$ as homoacetogenic acetate formation $\left(-26.2 \mathrm{~kJ}\right.$ per $\left.\mathrm{mol} \mathrm{H}_{2}\right)$, the yield of utilizable energy for the organism involved is close to zero (see above). Moreover, cleavage of propionate to acetate, $\mathrm{CO}_{2}$ and $\mathrm{H}_{2}$ is probably the energetically most difficult step in methanogenic degradation of fermentation intermediates, and seems to take just the same pathway backwards as outlined above for propionate synthesis (Koch et al. 1983; Schink 1985b). It is hard to see the advantage of forming propionate on the one side without significant energy gain, and decomposing it by the backwards reaction with a lot of effort on the other side. Nonetheless, our experiments with hydrogen addition to $D$. propionicus and $P$. propionicus cultures fermenting lactate or ethanol show, similar to the studies with the hydrogenasepositive Propionispira arboris (Thompson et al. 1984), that exogenously provided hydrogen can exert a significant influence on the fermentation balance of these propionateforming bacteria.

Acknowledgements. The authors are greatly indebted to Prof. Dr. N. Pfennig for support and to Klaas Dijkstra (Department of Physical
Chemistry, University of Groningen) for recording the NMR spectra. Technical help by E. Kayser with growth experiments is appreciated. This work was in part supported by a grant of the Deutsche Forschungsgemeinschaft.

\section{References}

Allen SHG, Linehan BA (1977) Presence of transcarboxylase in Arachnia propionica. Int J Syst Bacteriol 27:291-292

Allen SHG, Kellermeyer RW, Stjernholm RL, Wood HG (1964) Purification and properties of enzymes involved in the propionic acid fermentation. J Bacteriol 87:171-187

Bergmeyer HU (1974) Methoden der enzymatischen Analyse. Verlag Chemie, Weinheim

Boonstra J, Huttunen MT, Konings WN (1975) Anaerobic transport in Escherichia coli membrane vesicles. J Biol Chem 250:6792-6798

Bridger WA, Ramaley RF, Boyer PD (1969) Succinyl coenzyme A synthase from Escherichia coli. Meth Enzymol 13:70-75

Brockmann HL, Wood WA (1975) Electron-transferrring flavoprotein of Peptostreptococcus elsdenii that functions in the reduction of acrylyl-coenzyme A. J Bacteriol 124:1447-1453

Deeb SS, Hager LP (1974) Crystalline cytochrome $b_{1}$ from Escherichia coli. J Biol Chem 239:1024-1031

De Vries W, van Wyck-Kapteyn WMC, Stouthamer AH (1973) Generation of ATP during cytochrome-linked anaerobic electron transport in propionic acid bacteria. J Gen Microbiol $76: 31-41$

De Vries W, Aleem MJH, Hemrika-Wagner A, Stouthamer AH (1977 a) The functioning of cytochrome $b$ in the electron transport to fumarate in Propionibacterium freudenreichii and Propionibacterium pentosaceum. Arch Microbiol 112:271 - 276

De Vries W, Rietveld-Struijk TRM, Stouthamer AH (1977b) ATP formation associated with fumarate and nitrate reduction in growing cultures of Veillonella alcalescens. Antonie van Leeuwenhoek J Microbiol Serol 43:153-167

Dickerson RE, Timkovich R (1975) Cytochrome c. In: Boyer PD (ed) The Enzymes, vol XI, part A. Academic Press, New York San Francisco London, pp 397-547

Dijkhuizen L, van der Werf B, Harder W (1980) Metabolic regulation in Pseudomonas oxalaticus OX1. Diauxic growth on mixtures of oxalate and formate or acetate. Arch Microbiol $124: 261-268$

Friedrich B, Heine E, Finck A, Friedrich CG (1981) Nickel requirement for active hydrogenase formation in Alcaligenes eutrophus. J Bacteriol 145:1144-1149

Galivan JH, Allen SHG (1968) Methylmalonyl-coenzyme A decarboxylase. Its role in succinate decarboxylation by Micrococcus lactilyticus. J Biol Chem 243:1253-1261

Goldberg I, Cooney CL (1981) Formation of short-chain fatty acids from $\mathrm{H}_{2}$ and $\mathrm{CO}_{2}$ by a mixed culture of bacteria. Appl Environ Microbiol 41:148-154

Gottschalk G (1986) Bacterial metabolism. Springer, Berlin Heidelberg New York Tokyo

Hatchikian EC, LeGall J (1970) Etude du métabolisme des acide dicarboxyliques et du pyruvate chez les bactéries sulfato-reductrices. I. Etude de l'oxydation enzymatique du fumarate en acetate. Ann Inst Pasteur 118: 125-142

Hilpert W, Dimroth P (1983) Purification and characterization of a new sodium transport decarboxylase. Methylmalonyl-CoA decarboxylase from Veillonella alcalescens. Eur J Biochem $132: 579-587$

Hilpert W, Schink B, Dimroth P (1984) Life by a new decarboxylation-dependent energy conservation mechanism with $\mathrm{Na}^{+}$as coupling ion. EMBO J 3:1665-1670

International Union of Biochemistry (ed) (1984) Enzyme nomenclature 1984. Academic Press, New York

Koch M, Dolfing J, Wuhrmann K, Zehnder AJB (1983) Pathways of propionate degradation by enriched methanogenic cultures. Appl Environ Microbiol 45:1411-1414 
Kuenen JG, Veldkamp H (1972) Thiomicrospira pelophila nov. gen., nov. sp. a new obligately chemolithotrophic colourless sulfur bacterium. Antonie van Leeuwenhoek J Microbiol Serol 38: $241-256$

Laanbroek HJ, Abee T, Voogd JL (1982) Alcohol conversions by Desulfobulbus propionicus Lindhorst in the presence and absence of sulfate and hydrogen. Arch Microbiol 133:178-184

Lane MD, Chang HC, Miller RS (1969) Phosphoenolpyruvate carboxykinase from pig liver mitochondria. Methods Enzymol $13: 270-277$

Leaver FW, Wood HG, Stjernholm R (1955) The fermentation of three carbon substrates by Clostridium propionicum and Propionibacterium. J Bacteriol 70:521-530

Maeba P, Sanwal BD (1969) Phosphoenolpyruvate carboxylase from Salmonella typhimurium strain LT 2. Methods Enzymol 13:283-288

Odom JM, Peck HD (1981) Localization of dehydrogenases, reductases and electron transfer components in the sulfate-reducing bacterium Desulfovibrio gigas. J Bacteriol 147:161-169

Rogosa M (1974) Gram-negative anaerobic cocci. In: Buchanan RE, Gibbons NE (eds) Bergey's manual of determinative bacteriology, 8th edn. Williams and Wilkins, Baltimore, pp 445449

Samain E, Albagnac G, Dubourgier HC, Touzel JP (1982) Characterization of a new propionic acid bacterium that ferments ethanol and displays a growth factor dependent association with a gram negative homoacetogen. FEMS Microbiol Lett 15:69-74

Schink B (1984) Fermentation of 2,3-butanediol by Pelobacter carbinolicus sp. nov. and Pelobacter propionicus, sp. nov. and evidence for propionate formation from $\mathrm{C}_{2}$ compounds. Arch Microbiol 137:33-41

Schink B (1985a) Fermentation of acetylene by an obligate anaerobe, Pelobacter acetylenicus sp. nov. Arch Microbiol 142:295-301

Schink B (1985b) Mechanism and kinetics of succinate and propionate degradation in anoxic freshwater sediments and sewage sludge. J Gen Microbiol $131: 643-650$

Schink B, Pfennig N (1982) Fermentation of trihydroxybenzenes by Pelobacter acidigallici gen. nov. sp. nov., a new strictly anaerobic, non-sporeforming bacterium. Arch Microbiol 133:195201

Schink B, Thompson TE, Zeikus JG (1982) Characterization of Propionispira arboris gen. nov. sp. nov., a nitrogen-fixing anaerobe common to wetwoods of living trees. J Gen Microbiol 128:2771-2779

Schink B, Phelps TJ, Eichler B, Zeikus JG (1985) Comparison of ethanol degradation pathways in anoxic freshwater environments. J Gen Microbiol 131:65-660

Scrutton MC, Olmsted MR, Utter MF (1969) Pyruvate carboxylase from chicken liver. Methods Enzymol 13:235-249

Stams AJM, Hansen TA (1982) Oxygen labile L $(+)$ lactate dehydrogenase activity in Desulfovibrio desulfuricans. FEMS Microbiol Lett 13:389-394

Stams AJM, Kremer DR, Nicolay K, Wenk GH, Hansen TA (1984) Pathway of propionate formation in Desulfobulbus propionicus. Arch Microbiol 139:167-173

Stouthamer AH (1979) The search for correlation between theoretical and experimental growth yields. In: Quayle JR (ed) International review of biochemistry, microbial biochemistry, vol 21. University Park Press, Baltimore, pp 1-47

Stouthamer AH (1980) Electron transport linked phosphorylation in anaerobes. In: Gottschalk G, Pfennig N, Werner H (eds) Anaerobes and anaerobic infections. Fischer, Stuttgart New York, pp 17-29

Swick RW, Wood HG (1960) The role of transcarboxylation in propionic acid fermentation. Proc Natl Acad Sci USA 46:2841

Thauer RK, Jungermann K, Decker K (1977) Energy conservation in chemotrophic anaerobic bacteria. Bacteriol Rev 41:100180

Thompson TE, Conrad R, Zeikus JG (1984) Regulation of carbon and electron flow in Propionispira arboris: physiological function of hydrogenase and its role in homopropionate formation. FEMS Microbiol Lett 22:265-271

Wallnöfer P, Baldwin RL (1967) Pathway of propionate formation in Bacteroides ruminicola. J Bacteriol 93:504-505

Wood HG (1972) Transcarboxylase. In: Boyer PD (ed) The enzymes, vol 6. Academic Press, New York, pp 83-115

Wood HG, Davis JJ, Willard JM (1969) Phosphoenolpyruvate carboxytransphosphorylase from Propionibacterium shermanii. Methods Enzymol 13:297-309

Received December 9, 1986/Accepted February 20, 1987 